\title{
PENGEMBANGAN IPTEK DALAM TINJAUAN HUKUM ISLAM
}

\author{
Al Quddus Nofiandri Eko Sucipto Dwijo \\ (Dosen PAI FTK UIN Sunan Ampel)
}

\begin{abstract}
Abstrak:
Islam sangat mendukung umatnya untuk menemukan dan mengembangkan ilmu pengetahuan dan teknologi (Iptek). Dalam hal pengembangan Iptek, umat Islam dapat mempelajarinya dari orang-orang no-Islam, disamping juga dapat mengembangkan Iptek dari spirit ajaran Islam sendiri. Oleh karena produk keilmuan yang datang dari orang-orang non-Islam -secara umum- bersifat sekuleristik, maka setelah dipelajari, sebelum diadopsi dan diterpkan di dunia Islam, penting untuk terlebih dahulu diberikan nilainilai keislaman, agar tidak bertentangan dengan ajaranajaran hukum Islam. Ajaran hukum Islam secara normatif dan empirik sangat memulyakan orang-orang yang beriman dan berilmu dengan beberapa derajat. Dalam ajaran hukum Islam, ditegaskan bahwa tidak sama antara orang yang berilmu dengan orang yang tidak berilmu. Orang yang berilmu jelas lebih baik dan lebih utama daripada orang yang tidak berilmu. Dengan demikian, pengembagan ilmu pengetahuan dan teknologi dengan ragam modelnya (misal dengan bahasa Islamisasi Iptek) sangat dianjurkan oleh ajaran hukum Islam.
\end{abstract}

Kata Kunci: Ilmu, Islamisasi Ilmu, dan Hukum Islam 


\section{A. Pendahuluan}

Dalam masyarakat Islam, ilmu merupakan bagian yang tak terpisahkan dari nilai-nilai ketuhanan, karena sumber ilmu yang hakiki adalah Allah SWT. Manusia adalah ciptaan Allah SWT yang paling tinggi derajatnya dibandingkan dengan mahluk yang lain, karena manusia diberi daya berfikir, daya berfikir inilah yang menemukan teori-teori ilmiah dan teknologi. Pada waktu yang bersamaan, daya pikir tersebut menjadi bagian yang tak dapat dipisahkan dari keberadaan manusia sebagai makhluk Allah SWT. Oleh karenanya, manusia tidak hanya bertanggung jawab kepada sesamanya, tetapi juga kepada pencipta-Nya.

Meski begitu, perlu diingat bahwa ikatan agama yang terlalu kaku dan terstruktur kadang kala dapat menghambat perkembangan ilmu. Oleh karena itu, perlu kejelian dan kecerdasan memperhatikan sisi kebebasan dalam ilmu dan sistem nilai dalam agama agar keduanya tidak saling bertolak belakang. Di sinilah perlu rumusan yang jelas tentang ilmu secara filosofis, akademik dan agama agar ilmu dan teknologi tidak menjadi bagian yang lepas dari nilai-nilai agama dan kemanusiaan serta lingkungannya. ${ }^{1}$

Disamping itu, perlu dipertanyakan, apakah ilmu selalu merupakan berkah dan penyelamat bagi manusia? Apakah sudah terbukti, dengan kemajuan ilmu pengetahuan, manusia dapat menciptakan berbagai bentuk teknologi. Misalnya, pembuatan bom yang pada awalnya untuk memudahkan kerja manusia, namun kemudian dipergunakan untuk hal-hal yang bersifat negatif yang menimbulkan malapetaka bagi manusia itu sendiri. Di sinilah ilmu harus diletakkan secara proposional

\footnotetext{
${ }^{1}$ http://meetabied.wordpress.com/2009/11/01/kedudukan-filsafat-ilmu-dalamislamisasi-ilmu-pengetahuan-dan-kontribusinya-dalam-krisis-masyarakatmodern/ (Dikutip pada 14-12-2013).
} 
dan memihak pada nilai-nilai kebaikan dan kemanusiaan. Mengingat, jika ilmu tidak berpihak kepada nilai-nilai kebaikan, maka yang terjadi adalah bencana dan malapetaka.

Ide Islamisasi ilmu pengetahuan dan teknologi (Iptek) merupakan bagian dari upaya memberikan nilai-nilai Islam pada beragam keilmuan dengan ragam model pengembangannya. Beragam keilmuan dikembangkan dengan memberikan pandangan keislaman di dalamnya. Ide ini melahirkan pihakpihak yang pro dan kontra. Ada yang setuju dan ada yang kurang setuju. Dengan begitu, tidak ada salahnya jika ide Islamisasi Iptek ini ditinjau dari sisi hukum Islam.

\section{B. Konsep Iptek}

Ilmu adalah sesuatu yang diketahui secara ilmiah. Ilmu merupakan sesuatu yang penting bagi manusia, karena dengan ilmu semua keperluan dan kebutuhan manusia dapat terpenuhi secara lebih cepat dan lebih mudah. Merupakan kenyataan yang tidak dapat dipungkiri bahwa peradaban manusia sangat berhutang pada ilmu. Ilmu telah banyak mengubah wajah dunia seperti hal memberantas penyakit, kelaparan, kemiskinan dan berbagai wajah kehidupan yang sulit lainnya. Dengan kemajuan ilmu, manusia dapat merasakan kemudahan lainnya seperti transportasi, pemukiman, pendidikan, komunikasi, dan lain sebagainya. Singkatnya ilmu merupakan sarana untuk membantu manusia dalam mencapai tujuan hidupnya.

Setiap ilmu pengetahuan akan menghasilkan teknologi yang kemudian akan diterapkan pada masyarakat. Proses ilmu pengetahuan menjadi sebuah teknologi yang benar-benar dapat dimanfaatkan oleh masyarakat tentu tidak terlepas dari si ilmuwannya. Seorang ilmuwan akan dihadapkan pada kepentingan-kepentingan pribadi ataukah kepentingan masyarakat akan membawa pada persoalan etika keilmuan 
serta masalah bebas nilai. Untuk itulah tanggungjawab seorang ilmuwan harus dipupuk dan berada pada tempat yang tepat, tanggung jawab akademis, dan tanggung jawab moral. Penerapan ilmu pengetahuan yang telah dihasilkan oleh para ilmuwan, apakah itu berupa teknologi, ataupun teori-teori emansipasi masyarakat, mestilah memperhatikan nilai-nilai kemanusiaan, nilai agama, nilai adat, dan sebagainya. Ini berarti ilmu pengetahuan tersebut sudah tidak bebas nilai. karena ilmu sudah berada di tengah-tengah masyarakat luas dan masyarakat akan mengujinya.

Oleh karena itu, tanggung jawab lain yang berkaitan dengan teknologi di masyarakat, yaitu menciptakan hal yang positif. Akan tetapi, tidak semua teknologi atau ilmu pengetahuan selalu memiliki dampak positif. Di bidang etika, tanggung jawab seorang ilmuwan, bukan lagi memberi informasi namun harus memberi contoh. Dia harus bersifat objektif, terbuka, menerima kritik, menerima pendapat orang lain, kukuh dalam pendirian yang dianggap benar, dan berani mengakui kesalahan. Semua sifat ini, merupakan implikasi etis dari proses penemuan kebenaran secarah ilmiah. Di tengah situasi di mana nilai mengalami kegoncangan, maka seorang ilmuwan harus tampil ke depan. Pengetahuan yang dimilikinya merupakan kekuatan yang akan memberinya keberanian. ${ }^{2} \mathrm{Hal}$ yang sama harus dilakukan pada masyarakat yang sedang membangun, seorang ilmuwan harus bersikap sebagai seorang pendidik dengan memberikan contoh yang baik.

Ilmu pengetahuan harus terbuka pada konteksnya, dan agamalah yang menjadi konteksnya itu. Agama mengarahkan ilmu pengetahuan pada tujuan hakikinya, yakni memahami realitas alam, dan memahami eksistensi Allah SWT, agar

${ }^{2}$ Ibid. 
manusia menjadi sadar akan hakikat penciptaan dirinya. Solusi yang diberikan al-Quran terhadap ilmu pengetahuan yang terikat dengan nilai adalah dengan cara mengembalikan ilmu pengetahuan pada jalur semestinya, sehingga ia menjadi berkah dan rahmat kepada manusia dan alam, bukan sebaliknya, membawa mudharat.

Mengenai tujuan ilmu pengetahuan, ada beberapa perbedaan pendapat antara filosof dengan para ulama. Sebagian berpendapat bahwa pengetahuan sendiri merupakan tujuan pokok bagi orang yang menekuninya, dan mereka ungkapkan tentang hal ini dengan ungkapan, ilmu pengetahuan untuk ilmu pengetahuan, seni untuk seni, sastra untuk sastra, dan lain sebagainya. Menurut mereka ilmu pengetahuan hanyalah sebagai objek kajian untuk mengembangkan ilmu pengetahuan sendiri. Sebagian yang lain cenderung berpendapat bahwa tujuan ilmu pengetahuan merupakan upaya para peneliti atau ilmuwan menjadikan ilmu pengetahuan sebagai alat untuk menambahkan kesenangan manusia dalam kehidupan yang sangat terbatas dimuka bumi ini.

Menurut pendapat yang kedua ini, ilmu pengetahuan itu untuk meringankan beban hidup manusia atau untuk membuat manusia senang, karena dari lmu pengetahuan itulah yang nantinya akan melahirkan teknologi. Teknologi jelas sangat dibutuhkan oleh manusia untuk mengatasi berbagai masalah, dan lain sebagainya. Sementara itu pendapat yang lainnya cenderung menjadikan ilmu pengetahuan sebagai alat untuk meningkatkan kebudayaan dan kemajuan bagi umat manusia secara keseluruan. ${ }^{3}$

\footnotetext{
${ }^{3}$ Ibid.
} 


\section{Konsep Islamisasi Iptek}

Islamisasi ilmu pengetahuan pada dasarnya merupakan suatu respon terhadap krisis masyarakat modern yang disebabkan karena pendidikan Barat yang bertumpu pada suatu pandangan dunia yang lebih bersifat materialistis, sekularistis, relatifistis; yang menganggap bahwa pendidikan bukan untuk membuat manusia bijak, yakni mengenali dan mengakui posisi masing-masing dalam tertib realitas tapi memandang realitas sebagai sesuatu yang bermakna secara material bagi manusia, dan karena itu hubungan manusia dengan tertib realitas bersifat eksploitatif bukan harmonis. ${ }^{4}$ Ini adalah salah satu penyebab penting munculnya krisis masyarakat modern.

Islamisasi ilmu pengetahuan mencoba mencari akarakar krisis tersebut. Akar-akar krisis itu diantaranya dapat ditemukan dalam ilmu pengetahuan, yakni konsepsi atau asumsi tentang realitas yang dualistis, sekularistik, evolusioneristis, dan karena itu pada dasarnya bersifat realitifitas dan nihilistis. Islamisasi ilmu pengetahuan merupakan suatu upaya pembebasan pengetahuan dari asumsi-asumsi atau penafsiran-penafsiran Barat terhadap realitas, dan kemudian menggantikannya dengan pandangan dunia Islam.

Seperti apakah gagasan Islamisasi ilmu dapat dijalankan dan betul-betul menjadi solusi terhadap krisis masyarakat modern, barangkali sejarah yang akan membuktikannya. Apapun hasilnya nanti, gagasan ini perlu mendapat sambutan terutama dari mereka yang memiliki kepentingan dengan kondisi masyarakat modern. Selain itu Islamisasi ilmu

\footnotetext{
${ }^{4}$ Aminullah Elhady, "Naquib Al-Attas: Islamisasi Ilmu", dalam Khudlori Sholeh (Editor), Pemikiran Islam Kontemporer (Yogyakarta: Jendela, 2003), 331-332.
} 
pengetahuan juga muncul sebagai reaksi adanya konsep dikotomi antara agama dan ilmu pengetahuan yang dimasukkan masyarakat Barat dan budaya masyarakat modern. Masyarakat yang disebut terakhir ini misalnya memandang sifat, metode, struktur sains dan agama jauh berbeda, kalau tidak mau dikatakan kontradiktif. Sementara itu, sains meneropongnya dari segi objektifnya. Agama melihat problematika dan solusinya melalui petunjuk Allah SWT, sedangkan sains melalui eksprimen dan rasio manusia. Oleh karena ajaran agama diyakini sebagai petunjuk Allah SWT, kebenaran dinilai mutlak, sedangkan kebenaran sains relatif. Agama banyak berbicara yang gaib sedangkan sains hanya berbicara mengenai hal yang empiris.

Dalam perspektif sejarah, sains dan teknologi modern yang telah menunjukkan keberhasilannya dewasa ini mulai berkembang di Eropa dalam rangka gerakan renaissans pada tiga atau empat abad yang silam. Gerakan ini berhasil menyingkirkan peran agama dan mendobrak dominasi gereja Roma dalam kehidupan sosial dan intelektual masyarakat Eropa sebagai akibat dari sikap gereja yang memusuhi ilmu pengetahuan. ${ }^{5}$ Dengan kata lain ilmu pengetahuan di Eropa dan Barat mengalami perkembangan setelah memisahkan diri dari pengaruh agama. Setelah itu berkembanglah pendapatpendapat yang merendahkan agama dan meninggikan sains. Dalam perkembangannya, sains dan teknologi modern dipisahkan dari agama, karena kemajuaannya yang begitu pesat di Eropa dan Amerika sebagaimana yang disaksikan sampai sekarang. Sains dan teknologi yang demikian itu selanjutnya digunakan untuk mengabdi kepada kepentingan

\footnotetext{
${ }^{5}$ http://meetabied.wordpress.com/2009/11/01/kedudukan-filsafat-ilmu-dalamislamisasi-ilmu-pengetahuan-dan-kontribusinya-dalam-krisis-masyarakatmodern/ (Dikutip pada 14-12-2013). 
manusia semata-mata, yaitu untuk tujuan memuaskan hawa nafsunya, menguras isi alam untuk tujuan memuaskan nafsu konsumtif dan materialistik, menjajah dan menindas bangsabangsa yang lemah, melanggengkan kekuasaan dan tujuan lainnya.

Penyimpangan dari tujuan penggunaan ilmu pengetahuan itulah yang direspon melalui konsep Islamisasi ilmu pengetahuan, yaitu upaya menempatkan sains dan teknologi dalam bingkai Islam, dengan tujuan agar perumusan dan pemanfaatan sains dan teknologi itu ditunjukkan untuk mempertinggi harkat dan martabat manusia, melaksanakan fungsi kekhalifahannya di muka bumi serta tujuan-tujuan luhur lainnya. Inilah yang menjadi salah satu misi Islamisasi ilmu pengetahuan.

Berdasarkan penelusuran yang dilakukan oleh $\mathrm{Ummi}^{6} \mathrm{di}$ UIN Malang, ditemukan beberapa versi pemahaman tentang Islamisasi ilmu pengetahuan dan teknologi. Pertama beranggapan bahwa Islamisasi ilmu pengetahuan merupakan sekedar memberikan ayat-ayat yang sesuai dengan ilmu pengetahuan dan teknologi umum yang ada (ayatisasi). Kedua, mengatakan bahwa Islamisasi dilakukan dengan cara mengislamkan orangnya. Ketiga, Islamisasi yang berdasarkan filsafat Islam yang juga diterapkan di UIN Malang dengan mempelajari dasar metodologinya. Keempat memahami Islamisasi sebagai sebuah ilmu pengetahuan yang beretika atau beradab. Dengan berbagai pandangan dan pemaknaan yang muncul secara beragam ini perlu kiranya untuk diungkap agar lebih dipahami apa yang dimaksud "Islamisasi Ilmu Pengetahuan dan teknologi".

6 Ummi, Islamisasi Sains Perspektif UIN Malang, dalam Inovasi: Majalah Mahasiswa UIN Malang, Edisi 22. Th. 2005. 
Ismail Raji Al-Faruqi menyatakan bahwa Islamisasi adalah usaha "untuk mendefinisikan kembali, menyusun ulang data, memikirkan kembali argumen dan rasionalisasi yang berkaitan dengan data itu, menilai kembali kesimpulan dan tafsiran, memproyeksikan kembali tujuan-tujuan dan melakukan semua itu sedemikian rupa sehingga disiplindisiplin ini memperkaya wawasan Islam dan bermanfaat bagi cita-cita. ${ }^{7}$ Untuk menuangkan kembali keseluruhan khazanah pengetahuan umat manusia menurut wawasan Islam, bukanlah tugas yang ringan yang harus dihadapi oleh intelektualintelektual dan pemimpin-pemimpin Islam saat ini. Oleh karena itulah, untuk melandingkan gagasannya tentang Islamisasi ilmu, al-Faruqi meletakkan "prinsip tauhid" sebagai kerangka pemikiran, metodologi dan cara hidup Islam. Prinsip tauhid ini dikembangkan oleh al-Faruqi menjadi lima (5) macam kesatuan, yaitu: (1) Kesatuan Tuhan, (2) Kesatuan ciptaan, (3) Kesatuan kebenaran dan Pengetahuan, (4) Kesatuan kehidupan, dan (5) Kesatuan kemanusiaan. ${ }^{8}$

Islamisasi ilmu dimaksudkan untuk memberikan respon positif terhadap realitas ilmu pengetahuan modern yang sekularistik dan Islam yang "terlalu" religius, dalam model pengetahuan baru yang utuh dan integral tanpa pemisahan di antaranya. Sebagai panduan untuk usaha tersebut, al-Faruqi menggariskan satu kerangka kerja dengan lima tujuan dalam rangka Islamisasi ilmu, tujuan yang dimaksud adalah: 1. Penguasaan disiplin ilmu modern. 2. Penguasaan khazanah warisan Islam. 3. Membangun relevansi Islam dengan masingmasing disiplin ilmu modern. 4. Memadukan nilai-nilai dan khazanah warisan Islam secara kreatif dengan ilmu-ilmu

\footnotetext{
${ }^{7}$ Ismail Raji Al-Faruqi, Islamisasi Pengetahuan (Bandung: Pustaka, 1984).

${ }^{8}$ Ibid. 
modern. 5. Pengarahan aliran pemikiran Islam ke jalan-jalan yang mencapai pemenuhan pola rencana Allah SWT. ${ }^{9}$

Selain itu, ada beberapa pengembangan definisi dari Islamisasi ilmu pengetahuan dan teknologi tersebut. Sebagaimana yang diungkapkan oleh Osman Bakar, ${ }^{10}$ Islamisasi ilmu pengetahuan dan teknologi adalah sebuah program yang berupaya memecahkan masalah-masalah yang timbul karena perjumpaan antara Islam dengan sains modern sebelumnya. Progam ini menekankan pada keselarasan antara Islam dan sains modern tentang bagaimana sains dapat bermanfaat bagi umat Islam. M. Zainuddin ${ }^{11}$ menyimpulkan bahwa Islamisasi pengetahuan pada dasarnya adalah upaya pembebasan pengetahuan dari asumsi-asumsi Barat terhadap realitas dan kemudian menggantikannya dengan worldview-nya sendiri (Islam).

Sejak digagasnya ide Islamisasi ilmu pengetahuan oleh para cendikiawan muslim dan telah berjalan lebih dari 30 tahun, jika dihitung dari Seminar Internasional pertama tentang Pendidikan Islam di Makkah pada tahun 1977, berbagai respon terhadapnya pun mulai bermunculan, baik yang mendukung ataupun menolak, usaha untuk merealisasikan pun secara perlahan semakin marak dan beberapa karya yang berkaitan dengan ide Islamisasi mulai bermunculan di dunia Islam. Al-Attas sendiri sebagai penggagas ide ini telah menunjukkan suatu model usaha Islamisasi ilmu melalui karyanya, The Concept of Education in Islam. Dalam teks ini beliau berusaha menunjukkan hubungan antara bahasa dan pemikiran. Beliau menganalisis istilah-

\footnotetext{
${ }^{9}$ Ibid.

${ }^{10}$ Osman Bakar, Tauhid dan Sains (Bandung: Pustaka Hidayah, 1994)

${ }^{11}$ M. Zainuddin, Filsafat Ilmu: Perspektif Pemikiran Islam (Malang: Bayu Media, 2003).
} 
istilah yang sering dimaksudkan untuk mendidik seperti ta'lim, tarbiyah dan ta'dib, dan akhirnya mengambil kesimpulan bahwa istilah $t a^{\prime} d i b$ merupakan konsep yang paling sesuai dan komprehensif untuk pendidikan. ${ }^{12}$

Usaha ini kemudian dilanjutkan oleh cendekiawan muslim lainnya, sebut saja seperti Malik Badri (Dilema of a Muslim Psychologist, 1990); Wan Mohd Nor Wan Daud (The Concept of Knowledge in Islam,1989); dan Rosnani Hashim (Educational Dualism in Malaysia: Implications for Theory and Practice, 1996). Usaha dalam bidang psikologi seperti yang dilakukan Hanna Djumhana B. dan Hasan Langgulung, di bidang ekonomi Islam seperti Syafi'i Antonio, Adiwarman, Mohammad Anwar dan lain-lain. Bahkan hingga sekarang tercatat sudah lebih ratusan karya yang dihasilkan yang berbicara tentang Islamisasi ilmu pengetahuan, baik dalam bentuk buku, jurnal, majalah, artikel dan sebagainya. ${ }^{13}$

Setelah mengalami perjalanan yang cukup panjang, Islamisasi ilmu pengetahuan ini dinilai oleh beberapa kalangan belum memberikan hasil yang konkrit dan kontribusi yang berarti bagi umat Islam. Bahkan secara lugas editor American Journal of Islamic Social Sciences (AJISS) mengakui bahwa meskipun telah diadakan enam kali konferensi mengenai pendidikan Islam, yaitu di Makkah (1977), Islamabad (1980), Dakka (1981), Jakarta (1982), Kairo (1985), dan Amman (1990), dan berdirinya beberapa universitas yang memfokuskan pada Islamisasi pendidikan, namun hingga saat ini, tugas untuk menghasilkan silabus sekolah, buku-buku teks,

\footnotetext{
12 Miftahul Huda, Historisitas Islamisasi Ilmu Pengetahuan, dalam http://drmiftahulhudauin. multiply.com/journal/item/13 (Dikutip pada 14-122013).

${ }^{13}$ Ibid.
} 
dan petunjuk yang membantu guru di sekolah belum dilakukan. $^{14}$

Berdasarkan identifikasi Hanna Djumhana Bastaman, setelah cukup lama berkembang, Islamisasi melahirkan beberapa bentuk pola pemikiran, mulai dari bentuk yang paling superfisial sampai dengan bentuk yang agak mendasar. Bastaman mengistilahkannya sebagai; 1) Similarisasi, yaitu menyamakan begitu saja konsep-konsep yang berasal dari agama, padahal belum tentu sama; 2) Paralelisasi, yaitu menganggap paralel konsep yang berasal dari sains karena kemiripan konotasinya, tanpa mengidentikkan keduanya; 3) Komplementasi, yaitu antara sains dan agama saling mengisi dan saling memperkuat satu sama lain dengan tetap mempertahankan eksistensinya masing-masing; 4) Komparasi, yaitu membandingkan konsep/teori sains dengan konsep/wawasan agama mengenai gejala-gejala yang sama; 5) Induktifikasi, yaitu asumsi-asumsi dasar dari teori-teori ilmiah yang didukung oleh temuan-temuan empirik dilanjutkan pemikirannya secara teoritis-abstrak ke arah pemikiran metafisik, kemudian dihubungkan dengan prinsip-prinsip agama dan al-Quran mengenai hal tersebut; dan 6) Verifikasi, yaitu mengungkapkan hasil-hasil penelitian ilmiah yang menunjang dan membuktikan kebenaran ayat-ayat al-Quran. ${ }^{15}$

Keenam pola pemikiran yang diidentifikasi Bastaman di atas, masih menampakkan jurang pemisah antara keduanya, agama yang pada dasarnya bersumber dari keimanan yang bersifat metafisik tidak begitu saja dapat dihubungkan dengan

\footnotetext{
${ }^{14}$ Wan Mohd Nor Wan Daud, The Educational Philosophy and Practice of Syed Muhammad Naquib al-Attas, diterjemahkan oleh Hamid Fahmy dkk, Filsafat dan Praktik Pendidikan Islam Syed M. Naquib al-Attas (Bandung: Mizan, 1998).

15 Hanna Djumhana Bastaman, Integrasi Psikologi dengan Islam: Menuju Psikologi Islami (Yogyakarta: Pustaka Pelajar, 1997).
} 
ilmu pengetahuan yang lebih bercorak empirik dan merupakan produk akal dan intelektual manusia. Walau demikian, polapola pemikiran tersebut harus tetap dihargai sebagai upaya untuk Islamisasi ilmu pengetahuan. ${ }^{16}$

Konsep Islamisasi ilmu ini tidak hanya bisa diterapkan oleh umat Islam. Masyarakat non-Muslim pun bisa menyerapnya. Konsep Islamisasi bukanlah Arabisasi. Memang Islam bermula dari kandungan bahasa Arab. Islam adalah agama yang alami, bisa masuk ke seluruh dunia, bangsa, dan bahasa. Untuk setiap bangsa yang ingin memahami agama Islam, memang harus memahami bahasa Arab saat mempelajari kandungan ayat al-Quran. Akan tetapi, Islamisasi bukan Arabisasi. Islamisasi tidak sama dengan peng-araban. Walaupun untuk mengamalkan Islam tidak jauh dari budaya Arab, tapi bukan berarti budaya Arab yang dipahami itu Islam. Selain bukan Arabisasi, Islamisasi ilmu tidak berarti menolak budaya Barat. Islamisasi ilmu justru memasukkan berbagai hal penting dari budaya Barat ke dalam pandangan Islam. Tentunya, harus dalam rangka membentuk akhlak dan syariat Islami. $^{17}$

\section{Sejarah Islamisasi Iptek}

Wan Mohd Nor Wan Daud menyatakan bahwa proses Islamisasi ilmu pengetahuan dan teknologi pada dasarnya telah berlangsung sejak masa permulaan Islam hingga zaman sekarang ini. Ayat-ayat terawal yang diwahyukan kepada Nabi secara jelas menegaskan semangat Islamisasi ilmu

\footnotetext{
16 Miftahul Huda, Historisitas Islamisasi Ilmu Pengetahuan, dalam http:// drmiftahulhudauin. multiply.com/journal/item/13 (Dikutip pada 14-12-2013). 17 Wan Mohd Nor Wan Daud, Akhlak Mulia Lewat Islamisasi Ilmu, dalam http://www.mail-archive.com/daarut-tauhiid@yahoogroups.com/msg06276. html (Dikutip pada 14-12-2013).
} 
pengetahuan dan teknologi kontemporer, yaitu ketika Allah SWT menekankan bahwa Dia adalah sumber dan asal ilmu manusia. Ide yang disampaikan al-Quran tersebut membawa suatu perubahan radikal dari pemahaman umum bangsa Arab pra-Islam, yang menganggap suku dan tradisi kesukuan serta pengalaman empiris, sebagai sumber ilmu pengetahuan dan kebijaksanaan. ${ }^{18}$

Pada masa pemerintahan Daulah Bani Abbasiyah (sekitar abad ke-8 M), proses Islamisasi ilmu ini berlanjut secara besar-besaran, yaitu dengan dilakukannya penerjemahan terhadap karya-karya dari Persia dan Yunani yang kemudian diberikan pemaknaan ulang disesuaikan dengan konsep agama Islam. Salah satu karya besar tentang usaha Islamisasi ilmu adalah hadirnya karya Imam al-Ghazali, Tahafut al-Falasifah, yang menonjolkan 20 ide yang asing dalam pandangan Islam yang diambil oleh pemikir Islam dari falsafah Yunani, beberapa di antara ide tersebut bertentangan dengan ajaran Islam yang kemudian dibahas oleh al-Ghazali disesuaikan dengan konsep aqidah Islam. Hal yang sedemikian tersebut, walaupun tidak menggunakan pelabelan Islamisasi, tapi aktivitas yang sudah dilakukan senafas dengan makna Islamisasi. $^{19}$

Selain itu, pada tahun 1930-an, Muhammad Iqbal menegaskan akan perlunya melakukan proses Islamisasi terhadap ilmu pengetahuan. Dia menyadari bahwa ilmu yang dikembangkankan oleh Barat telah bersifat ateistik, sehingga bisa menggoyahkan aqidah umat, sehingga beliau menyarankan umat Islam agar "mengonversikan ilmu pengetahuan modern". Akan tetapi, Iqbal tidak melakukan

\footnotetext{
${ }^{18}$ Wan Mohd Nor Wan Daud, The Educational Philosophy ... Op.Cit.

19 Miftahul Huda, Historisitas Islamisasi Ilmu Pengetahuan, dalam http:// drmiftahulhudauin. multiply.com/journal/item/13 (Dikutip pada 14-12-2013).
} 
tindak lanjut atas ide yang dilontarkannya tersebut. Tidak ada identifikasi secara jelas problem epistemologis mendasar dari ilmu pengetahuan modern Barat yang sekuler itu, dan juga tidak mengemukakan saran-saran atau program konseptual atau metodologis untuk megonversikan ilmu pengetahuan tersebut menjadi ilmu pengetahuan yang sejalan dengan Islam.

Ide Islamisasi ilmu pengetahuan ini dimunculkan kembali oleh Sayyed Hossein Nasr, pemikir muslim Amerika kelahiran Iran, tahun 60-an. Dia menyadari akan adanya bahaya sekularisme dan modernisme yang mengancam dunia Islam, karena itulah beliau meletakkan asas untuk konsep sains Islam dalam aspek teori dan praktikal melalui karyanya Science and Civilization in Islam (1968) dan Islamic Science (1976). Nasr mengklaim bahwa ide-ide Islamisasi yang muncul kemudian merupakan kelanjutan dari ide yang pernah dilontarkannya. ${ }^{20}$

Gagasan tersebut kemudian dikembangkan oleh Naquib Al-Attas sebagai proyek "Islamisasi" yang mulai diperkenalkannya pada Konferensi dunia mengenai Pendidikan Islam yang Pertama di Makkah pada tahun 1977. Al-Attas dianggap sebagai orang yang pertama kali mengupas dan menegaskan tentang perlunya Islamisasi pendidikan, Islamisasi sains, dan Islamisasi ilmu. Dalam pertemuan itu beliau menyampaikan makalah yang berjudul "Preliminary Thoughts on the Nature of Knowledge and the Definition and Aims of Education". Ide ini kemudian disempurnakan dalam bukunya Islam and Secularism (1978) dan The Concepts of Education in Islam A Framework for an Islamic Philosophy of Education (1980). Persidangan inilah yang kemudian dianggap sebagai pembangkit proses Islamisasi selanjutnya. ${ }^{21}$

${ }^{20}$ Ibid.

${ }^{21}$ Ibid. 
Gagasan awal dan saran-saran konkret yang diajukan alAttas, tak pelak, mengundang pelbagai reaksi dan salah satunya adalah Ismail Raji al-Faruqi dengan agenda Islamisasi Ilmu Pengetahuannya. Sampai saat ini gagasan Islamisasi ilmu menjadi misi dan tujuan terpenting (raison d'etre) bagi beberapa institusi Islam seperti International Institute of Islamic Thought (IIIT), International Islamic University Malaysia (IIUM), Akademi Islam di Cambridge dan International Institute of Islamic Thought and Civilization (ISTAC) di Kuala Lumpur.

\section{E. Strategi Pengembangan Islamisasi Iptek}

Pemisahan agama dari ilmu pengetahuan sebagaimana tersebut di atas terjadi pada abad pertengahan, yaitu pada saat umat Islam kurang mempedulikan (meninggalkan) iptek. Pada masa itu yang berpengaruh di masyarakat Islam adalah ulama tarikat dan ulama fiqih. Keduanya menanamkan paham taklid dan membatasi kajian agama hanya dalam bidang yang sampai sekarang masih dikenal sebagai ilmu-ilmu agama seperti tafsir, fiqih,dan tauhid. Ilmu tersebut mempunyai pendekatan normatif dan tarekat, tarekat hanyut dalam wirit dan dzikir dalam rangka menyucikan jiwa dan mendekatkan diri pada Allah SWT dengan menjauhkan kehidupan duniawi.

Beberapa ulama tidak tertarik mempelajari alam dan kehidupan manusia secara objektif; bahkan ada yang mengharamkan untuk mempelajari filsafat, padahal dari filsafatlah iptek dapat berkembang pesat. Keadaan ini mengalami perubahan pada akhir abad ke-19, yaitu sejak ideide pembaharuan diterima dan didukung oleh sebagian umat. Mereka mengkritik pengembangan sains dan teknologi modern yang dipisahkan dari ajaran agama, seperti dikemukakan oleh Muhammad Naquib al-Attas (1981: 47-56) Ismail Raji al-Faruqi 
(1982: 3-8) dengan tujuan agar ilmu pengetahuan dapat membawa kepada kesejahteraan bagi umat manusia.

Para ilmuwan dan cendekiawan muslim menganggap bahwa pengembangan iptek perlu dikembalikan pada kerangka dan perspektif ajaran Islam. Al-Faruqi menyerukan perlunya dilaksanakan Islamisasi sains. Sejak itu gerakan Islamisasi ilmu pengetahuan digulirkan, dan kajian mengenai Islam dalam hubungannya dengan pengembangan iptek mulai digali dan diperkenalkan. ${ }^{22}$ Sebagaimana diketahui bahwa salah satu gagasan yang paling canggih, amat komperhensif dan mendalam yang ditemukan dalam al-Qur'an ialah konsep 'ilm. Pentingnya konsep ini terungkap dalam kenyataan turunnya sekitar 800 kali. Dalam sejarah peradaban Islam, konsep ilmu secara mendalam meresap ke dalam seluruh lapisan masyarakat dan mengungkapkan dirinya dalam semua upaya intelektual. Tidak ada peradaban lain yang memiliki konsep pengetahuan dengan semangat yang sedemikian tinggi dan mengajarkannya dengan amat tekun seperti itu.

Munawar Ahmad Aness menyatakan bahwa dalam konsep Islam yang berdasarkan al-Qur'an, upaya menerjemahkan ilmu sebagai pengetahuan berarti melakukan suatu kejahatan. Walaupun tidak disengaja, terhadap konsep yang luhur dan multi dimensional ini. Ilmu memang mengandung unsur-unsur dari apa yang dipahami sekarang sebagai pengetahuan. Akan tetapi ia juga digambarkan sebagai hikmah. Selanjutnya jika di Eropa sains dan teknologi dapat berkembang sesudah mengalahkan dominasi gereja, sedangkan dalam perjalanan sejarah Islam, ilmu dalam berbagai bidangnya mengalaami kemajuan yang pesat di dunia Islam

\footnotetext{
${ }^{22}$ http://meetabied.wordpress.com/2009/11/01/kedudukan-filsafat-ilmu-dalamislamisasi-ilmu-pengetahuan-dan-kontribusinya-dalam-krisis-masyarakatmodern/ (Dikutip pada akses 14-12-2013). 
pada zaman klasik (670-1300 M), yaitu zaman Nabi Muhammad sampai dengan akhir masa Daulah Abbasiyah di Baghdad.

Pada masa itu, dunia Islam telah memainkan peran penting baik dalam bidang ilmu pengetahuan agama maupun pengetahuan umum. Dalam kaitan ini Harun Nasution menyatakan bahwa cendikiawan-cendikiawan muslim bukan hanya mempelajari ilmu pengetahuan dan filsafat dari bukubuku Yunani, tetapi hal itu mereka tambahkan ke dalam hasilhasil penyelidikan yang dilakukan sendiri dalam lapangan ilmu pengetahuan dan hasil pikiran mereka dalam ilmu filsafat. Para ilmuwan tersebut memiliki pengetahuan yang bersifat integrated, yakni bahwa ilmu pengetahuan umum yang mereka kembangakan tidak terlepas dari ilmu agama atau tidak terlepas dari nilai-nilai Islam.

Dalam rangka pengembangan Islamisasi Iptek, Al-Faruqi menyusun 12 langkah yang harus ditempuh terlebih dahulu. Langkah-langkah tersebut adalah: 1. Penguasaan disiplin ilmu modern: prinsip, metodologi, masalah, tema dan perkembangannya. 2. Survei disiplin ilmu. 3. Penguasaan khazanah Islam: ontologi. 4. Penguasaan khazanah ilmiah Islam: analisis. 5. Penentuan relevansi Islam yang khas terhadap disiplin-disiplin ilmu. 6. Penilaian secara kritis terhadap disiplin keilmuan modern dan tingkat perkembangannya di masa kini. 7. Penilaian secara kritis terhadap khazanah Islam dan tingkat perkembangannya dewasa ini. 8. Survei permasalahan yang dihadapi umat Islam. 9. Survei permasalahan yang dihadapi manusia. 10. Analisis dan sintesis kreatif. 11. Penuangan kembali disiplin ilmu 
modern ke dalam kerangka Islam. 12. Penyebarluasan ilmu yang sudah diislamkan. ${ }^{23}$

Untuk mengaplikasikan Islamisasi ilmu, dapat dimulai dari level ilmu yang ada di perguruan tinggi. Level TK sampai SMA juga penting, tapi mereka sebenarnya bergantung pada guru-guru yang mengajar mereka. Guru yang mengajar TK sampai SMA, semuanya produk dari perguruan tinggi. Penulispenulis buku pun kebanyakan dibuat oleh (lulusan) perguruan tinggi. Jadi, walaupun targetnya sekolah dasar, yang harus diubah pertama adalah guru-gurunya. Di Malaysia, proses Islamisasi mulai berlaku dalam hal tertentu, karena politik kerajaan di Malaysia memberikan perhatian khusus pada masalah pendidikan. Di Indonesia pun usaha-usaha untuk menerapkan pandangan Islam sudah ada. ${ }^{24}$

\section{F. Pengembangan Iptek dalam Tinjauan Hukum Islam}

Berdasarkan tinjauan hukum Islam ilmu tidaklah berkembang pada arah yang tak terkendali, tapi ia harus bergerak pada arah maknawi dan umat manusia berkuasa untuk mengendalikannya. Kekuasaan manusia atas ilmu pengetahuan dan teknologi harus mendapatkan tempat yang utuh. Eksistensi ilmu pengetahuan dan teknologi bukan melulu untuk mendesak kemanusiaan, tetapi kemanusiaanlah yang menggenggam ilmu pengetahuan untuk kepentingan dirinya dalam rangka penghambaan diri kepada sang Pencipta.

Konsep ajaran Islam tentang pengembangan ilmu pengetahuan dan teknologi yang demikian itu didasarkan kepada beberapa prinsip sebagai berikut. ${ }^{25}$

\footnotetext{
${ }^{23}$ Al-Faruqi, Islamisasi...Op.Cit.

${ }^{24}$ Ibid.

${ }^{25}$ Ibid. 
Pertama, ilmu pengetahuan dan teknologi dalam Islam dikembangkan dalam kerangka tauhid atau teologi. Teologi yang bukan semata-mata meyakini adanya Allah SWT dalam hati, mengucapkannya dengan lisan dan mengamalkannya dengan tingkah laku, melainkan teologi yang menyangkut aktivitas mental berupa kesadaran manusia yang paling dalam perihal hubungan manusia dengan Tuhan, lingkungan dan sesamanya. Lebih tegasnya adalah teologi yang memunculkan kesadaran, yakni suatu "matra yang paling dalam" dari diri manusia yang menformat pandangan dunianya, yang kemudian menurunkan pola sikap dan tindakan yang selaras dengan pandangan dunia itu. Oleh karena itu teologi pada ujungnya akan mempunyai implikasi yang sangat sosiologis, sekaligus antropologis.

Kedua, ilmu pengetahuan dan teknologi dalam Islam hendaknya dikembangkan dalam rangka bertakwa dan beribadah kepada Allah SWT. Hal ini penting ditegaskan, karena dorongan al-Qur'an untuk mempelajari fenomena alam dan sosial tampak kurang diperhatikan, sebagai akibat dan dakwah Islam yang semula lebih tertuju untuk memperoleh keselamatan di akhirat. Hal ini mesti diimbangi dengan perintah mengabdi kapada Allah SWT dalam arti yang luas, termasuk mengembangkan Iptek.

Ketiga, Ilmu pengetahuan dan teknologi harus dikembangkan oleh orang-orang Islam yang memilki keseimbangan antara kecerdasan akal, kecerdasan emosional dan sepiritual yang dibarengi dengan kesungguhan untuk beribadah kepada Allah SWT dalam arti yang seluas-luasnya. Hal ini sesuai dengan apa yang terjadi dalam sejarah di abad klasik, dimana para ilmuwan yang mengembangkan ilmu pengetahuan adalah pribadi-pribadi yang senantiasa taat beribadah kepada Allah SWT. 
Keempat, Ilmu pengetahuan dan teknologi harus dikembangkan dalam kerangka yang integral, yakni bahwa antara ilmu agama dan ilmu umum walaupun bentuk formalnya berbeda-beda, namun hakikatnya sama, yaitu samasama sebagai tanda kekuasaan Allah SWT. Dengan pandangan yang demikian itu, maka tidak ada lagi perasaan yang lebih unggul antara satu dan lainnya. Dengan menerapkan keempat macam setrategi pengembangan ilmu pengetahuan tersebut, maka akan dapat diperoleh keuntungan yang berguna untuk mengatasi problem kehidupan masyarakat modern sebagaimana tersebut di atas.

Malaysia lebih memperhatikan pendidikan Islami. Misalnya, dalam hal yang melanggar tata krama. Kalau pejabat itu beragama Islam, mereka wajib merencanakan kemajuan Islamisasi ilmu yang akan berdampak pada akhlak masyarakatnya. Dalam menerapkan konsep Islamisasi ilmu tidak boleh mencampakkan hak orang yang bukan Islam. Mereka harus diperlakukan seadilnya. Begitu juga jangan sampai untuk menjaga hak non-Islam, hak orang Islam sendiri malah dikorbankan. Masyarakat non-Islam sendiri tidak perlu khawatir dengan Islamisasi ilmu. Kalau Islamisasi berjalan baik, semua umat apa pun agamanya akan mendukung. Kalau Islamisasi sukses, akan menjamin umat Islam lebih berakhlak dan akan lebih menjamin hak-hak ekonomi serta politik semua umat, termasuk non-Muslim. Kalau memiliki akhlak yang baik dan bisa menjaga hati nurani, masyarakat tidak akan memilih pemimpin yang rusak, sehingga semua negara akan dipimpin oleh pemimpin yang baik. 


\section{G. Penutup}

Dari uraian di atas dapat ditegaskan bahwa Islam sangat mendukung umatnya untuk menemukan dan mengembangkan ilmu pengetahuan dan teknologi (Iptek). Dalam hal pengembangan Iptek, umat Islam dapat mempelajarinya dari orang-orang no-Islam, disamping juga dapat mengembangkan Iptek dari spirit ajaran Islam sendiri. Oleh karena produk keilmuan yang datang dari orang-orang non-Islam -secara umum- bersifat sekuleristik, maka setelah dipelajari, sebelum diadopsi dan diterpkan di dunia Islam, penting untuk terlebih dahulu diberikan nilai-nilai keislaman, agar tidak bertentangan dengan ajaran-ajaran hukum Islam.

Ajaran hukum Islam secara normatif dan empirik sangat memulyakan orang-orang yang beriman dan berilmu dengan beberapa derajat. Dalam ajaran hukum Islam, ditegaskan bahwa tidak sama antara orang yang berilmu dengan orang yang tidak berilmu. Orang yang berilmu jelas lebih baik dan lebih utama daripada orang yang tidak berilmu. Dengan demikian, pengembagan ilmu pengetahuan dan teknologi dengan ragam modelnya (misal dengan bahasa Islamisasi Iptek) sangat dianjurkan oleh ajaran hukum Islam.

\section{DAFTAR PUSTAKA}

Aminullah Elhady, "Naquib Al-Attas: Islamisasi Ilmu", dalam Khudlori Sholeh (Editor), Pemikiran Islam Kontemporer (Yogyakarta: Jendela, 2003).

Hanna Djumhana Bastaman, Integrasi Psikologi dengan Islam: Menuju Psikologi Islami (Yogyakarta: Pustaka Pelajar, 1997). 
http://meetabied.wordpress.com/2009/11/01/kedudukan-filsafat-ilmudalam-islamisasi-ilmu-pengetahuan-dan-kontribusinyadalam-krisis-masyarakat-modern/ (Dikutip pada 14-122013).

Ismail Raji Al-Faruqi, Islamisasi Pengetahuan (Bandung: Pustaka, 1984).

M. Zainuddin, Filsafat Ilmu: Perspektif Pemikiran Islam (Malang: Bayu Media, 2003).

Miftahul Huda, Historisitas Islamisasi Ilmu Pengetahuan, dalam http://drmiftahulhudauin. multiply.com/journal/item/13 (Dikutip pada 14-12-2013).

Osman Bakar, Tauhid dan Sains (Bandung: Pustaka Hidayah, 1994)

Ummi, Islamisasi Sains Perspektif UIN Malang, dalam Inovasi: Majalah Mahasiswa UIN Malang, Edisi 22. Th. 2005.

Wan Mohd Nor Wan Daud, Akhlak Mulia Lewat Islamisasi Ilmu, dalam http://www.mail-archive.com/daaruttauhiid@yahoogroups.com/msg06276.html_ (Dikutip pada 14-12-2013).

Wan Mohd Nor Wan Daud, The Educational Philosophy and Practice of Syed Muhammad Naquib al-Attas, diterjemahkan oleh Hamid Fahmy dkk, Filsafat dan Praktik Pendidikan Islam Syed M. Naquib al-Attas (Bandung: Mizan, 1998). 